Indonesian Journal of Medicine (2019), 4(4): 376-382

https://doi.org/10.26911/theijmed.2019.04.04.11

\title{
The Effect of Holistic Programs on Cortisol Serum Levels in Polycistic Ovarium Syndrome
}

\author{
Erna Yovi Kurniawati'), Suharyo Hadisaputro²), Agus Suwandono3) \\ ${ }^{1)}$ Masters Program in Applied Midwifery, School of Health Sciences, Ministry of Health Semarang \\ ${ }^{2}$ School of Health Sciences, Ministry of Health Semarang \\ 3)Universitas Diponegoro, Semarang, Central Java
}

\begin{abstract}
Background: The increasing prevalence of polycystic ovary syndrome (PCOS) in Indonesia reaches $8-10 \%$. Patients with polycystic ovary syndrome are at risk of experiencing complex psychological disorders and decreased well-being. Psychological disorders in polycystic ovary syndrome are at risk of developing physical symptoms and increasing insulin resistance. The Holistic Program consists of a combination of diet yoga and remembrance therapy as an integrated holistic therapy. There is no non-pharmacological therapy that is holistically integrated to reduce serum cortisol levels in polycystic ovary syndrome. This study aimed to examine the effect of holistic programs on cortisol serum levels in polycistic ovarium syndrome.

Subjects and Method: This was a randomized controlled trials conducted in Yogyakarta. A sample of 30 women patients with PCOS aged 19-40 years old was selected for this study. The sample was divided into 2 groups. The intervention group received holistic program for 14 days. The dependent variable was cortisol serum. The independent variable was holistic program. Cortisol serum and insulin levels were measure by ELISA method at the Integrated Research and Testing Laboratory, Universitas Gadjah Mada, Yogyakarta. Insulin resistance was calculated using the HOMA IR method. The data were analyzed by independent t-test and different test Paired ttest

Results: Serum cortisol levels in the intervention group were lower than the control group. Serum cortisol levels decrease after the implementation of a holistic program.

Conclusion: The holistic program that was carried out for 14 days in polycystic ovary syndrome is effective to reduce serum cortisol levels.
\end{abstract}

Keywords: holistic program, cortisol serum, polycystic ovary syndrome

\section{Correspondence:}

Erna Yovi Kurniawati. Masters Program in Applied Midwifery, School of Health Polytechnics, Ministry of Health Semarang. Jl. Tirto Agung, Pedalangan, Banyumanik, Semarang 50239, Central Java. Mobile: +6287739122352. Email: yovi.raharjanto@gmail.com

\section{BACKGROUND}

Polycystic ovary syndrome (PCOS) affects about $5-10 \%$ of women in their reproductive period. The trend of the prevalence of polycystic ovary syndrome is increasing, even reported an increase in prevalence reaching 8-10\% (Sirmans et al., 2014). More than two-thirds (69\%) of women aged 18-40 years experience obesity or obesity (Santoso, 2014), PCOS women who are overweight or obese represent a large group at risk of developing cardiometabolic and psychological disorders (Sarfarina et al., 2016).

Women with PCOS develop an increased risk of experiencing psychological distress and reduce welfare. The prevalence of PCOS women who experienced emotional disturbances was reported to be $38 \%$, depression 21-46\%, and anxiety 34\%. PCOS is associated with long-term mental health risks, such as sexual disorders, welfare dis- 
orders, disorders mood, anxiety, depression and other stress-related symptoms (Bazarganipour et al., 2013). Clinical stressors can be measured through the hormone cortisol. Stress can increase cortisol levels which can affect other endocrine functions in the body and also affect insulin resistance and an ovulation.

Types of drugs developed and proven to manage the symptoms of polycystic ovary syndrome include oral contraceptives, progestogens, sensitizers insulin, and antiandrogen agents. The current treatment of polycystic ovary syndrome is difficult, long, expensive, and tends to emphasize only the physical aspects, using various hormonal drugs that must be consumed every day and can cause dependency and hyperstimulation effects (Costello et al., 2014). Treatment long and long can cause severe psychological impact for women with polycystic ovary syndrome, so that treatment becomes ineffective because the psychological aspects that are very influential are not handled,

Non-pharmacological companion therapy in PCOS including eating arrangements (Marsh et al., 2009), yoga (Nidhi et al., 2012), mindfulness-based stress reduction uses meditation and relaxation techniques (Raja et al., 2015), phytotherapy (Rooney et al., 2014), acupuncture (Stener et al., 2013), antioxidants (Amini et al., 2015), and Ayurveda (Shama et al., 2017). There is no integrated therapy combined to realize holistic, comprehensive health $\mathrm{n}$ balanced. Holistic research that combines complementary physical, psychological and spiritual therapy has not been done.

The holistic program consists of therapies that accompany physical, psychological and spiritual aspects that are integrated as a companion therapy in PCOS. A holistic program is a combination of therapies consisting of a therapy diet, yoga, and therapeutic remembrance. The therapeutic diet is intended as a companion to physical therapy, yoga consists of physical exercise and breathing is intended as a companion to physical and psychological therapy, while dhikr is intended as a companion to spiritual and psychological therapy.

\section{SUBJECTS AND METHOD}

\section{Study Design}

This was a randomized controlled trials. The study was conducted at Integrated Research and Testing Laboratory, Universitas Gadjah Mada, Yogyakarta.

\section{Study Subjects}

A sample of 30 women aged 19-40 years with PCOS in Yogyakarta, was selected for this study. The sample was divided into 2 groups. The intervention group received holistic program for 14 days

\section{Study Variable}

The dependent variable was serum cortisol level. The independent variable was holistic program.

\section{Operational Definition of Variables} Holistic program was a series of holistic based therapy programs, consisting of physical therapy with diet and yoga methods, therapy mind and soul with the dhikr method, which is specifically for women with polycystic ovary syndrome.

Serum cortisol levels of women with polycystic ovary syndrome were tested using the ELISA method.

\section{Study Instrument}

Serum cortisol levels were measured using the ELISA method using ELISA KIT EIA 1887 DRG reagent. International $\mathrm{GmbH}$ Germany at the UGM LPPT laboratory.

\section{Data Analysis Data}

Analysis using independent t-test and different test using a paired t-test.

\section{Research Ethics}

Research ethics by the Bioethics Commission on Medical/ Health Research, The Me- 
dical Faculty of Sultan Agung Islamic University Semarang with Ethical Clearance Number 243/VII/2018/. Bioethics Commission was declared to have met the prerequisites of research ethics.

\section{Sample Characteristics}

Mean age of respondents was 30.33 in the intervention group and 30.47 in the control group with the highest range aged 27-30 years totaling 19 people (63.33\%) and there were no differences in variance between the two groups with $\mathrm{p}=0.469$. The mean length of the marriage of 4.53 respondents in the intervention group and 4.60 in the control group with a long-married range was the same as in the control and intervention groups. There were no differences between the old married variants between the intervention group and the control group with $\mathrm{p}=0.104$. The mean duration of treatment of respondents was 25.93 in the intervention group and 23.93 in the control group with the highest treatment duration of 6-24 months totaling 18 people (60\%) and there were no differences in variance between the two groups with $\mathrm{p}=0.957$.

13 women had bachelor education level (86.7\%) in the intervention group, as well as 12 women (80\%) in the control group. Women as housewives were 1 person (6.7\%), 1 person (6.7\%) as an entrepreneur, 11 people (73.3\%) as private employees, and 2 people (13.3\%) as civil servants in the intervention group.

As many as 2 women (13.3\%) were not worked, 1 person $(6.7 \%)$ as entrepreneurs, 7 people $(46.7 \%)$ as private employees, and 5 people (33.3\%) as civil servants.

\section{Measurement of cortisol serum levels before and after a holistic program}

Table 1 showed cortisol serum levels before and after holistic program. Table 1 showed that there was no significant difference in the effect of cortisol serum levels before holistic program $(\mathrm{p}=0.966)$.

Table 1 showed that cortisol serum levels in the intervention group (Mean= 1.32; $\mathrm{SD}=0.09$ ) was lower than control group $($ Mean $=2.16 ; \mathrm{SD}=0.18)$, and it was statistically significant $(\mathrm{p}<0.001)$.

Table 1. Cortisol serum levels before and after holistic program

\begin{tabular}{lccc}
\hline \multirow{2}{*}{ Cortisol Serum Levels } & \multicolumn{2}{c}{ Group } & \multirow{2}{*}{ p } \\
\cline { 2 - 3 } & Intervention & Control & \\
\cline { 2 - 3 } & Mean \pm SD & Mean \pm SD & 0.966 \\
Pre intervention & $2.05 \pm 0.21$ & $2.06 \pm 0.14$ & 0.000 \\
Post intervention & $1.32 \pm 0.09$ & $2.16 \pm 0.18$ & \\
\hline
\end{tabular}

Table 2. Serum cortisol differences in intervention and control groups

\begin{tabular}{cllc}
\hline \multicolumn{1}{c}{ Variable } & \multicolumn{1}{c}{ Group } & \multicolumn{1}{c}{ Mean \pm SD } & p \\
\hline Cortisol Serum & Control & $38.53 \pm 67.00$ & 0.043 \\
& Intervention & $106.66 \pm 66.27$ & $<0.001$ \\
Difference in Cortisol Level Serum & & $145.2 \pm 107.79$ & $<0.001$ \\
\hline
\end{tabular}

Based on the statistical test results in Table 2, It can be concluded that there are significant differences in serum cortisol levels in the control group $(\mathrm{p}=0.043)$, with an increase in mean (38.5) serum cortisol levels. There were significant differences in serum cortisol levels in the intervention group $(\mathrm{p}<0.001)$. There is a significant difference in the difference between serum cortisol levels $(\mathrm{p}<0.001)$. 


\section{DISCUSSIONS}

The results reveal that the cortisol levels in polycystic ovary syndrome showed the average levels in the range high of the control group with a mean of 121.27 and the intervention group with a mean of 128.7 . High cortisol levels in patients with polycystic ovary syndrome can be caused by various factors. The factor stressor most potential based on anamnesis results found the stressor greatest is infertility 13 women (40\%), family problems 6 women (20\%), suffering from PCOS 5 women (16\%), work problems 4 women (14\%) and problems of obesity 3 women (10\%). Processor experienced by patients with polycystic ovary syndrome, causing the body to react to stress by releasing two types of chemicals, namely hormones in the blood and neurotransmitters in the brain (Adisty et al., 2017). Stress conditions will cause CRF secretion by the hypothalamus to increase, an increase in CRF levels will trigger an increase in the level of ACTH by the pituitary, eventually activating the adrenal cortex so that glucocorticoid secretion, especially cortisol increases (Helpman et al., 2017).

In line with the theory and results of previous studies showed that in stressful conditions in people with PCOS, neurons in the hippocampus are damaged due to exposure to the hormone cortisol. Long-term exposure will result in a decrease in hippocampal function, especially in memory formation and can decrease permanently, this is very dangerous considering the damage to neuronal cells will be much more difficult to recover than damage to other body cells. Neuron cells do not have the ability to regenerate as well as other cells because neuronal cell development will decrease as we age. High cortisol levels in the body can lead to a behavior called foodseeking behavior (the desire to eat in large portions or frequent frequencies when the body is in a state of anger, irritation, or stress). The body stores excess calories as fat deposits in the abdomen, which can lead to weight gain and an increased risk of diabetes and heart attacks. Increased cortisol in people with PCOS, affects the increase in levels of insulin resistance so as to develop or improve symptoms in polycystic ovary syndrome (Helpman et al., 2017).

Serum cortisol levels decreased in the intervention group which performed a holistic program with an average decrease in serum cortisol levels of 106.67 when compared with the control group that carried out standard SOPK drug therapy from SpOG doctors, serum cortisol levels increased with an average increase of 38.53 . The management of mind and soul therapy in a holistic program will be responded by the lateral nuclei and ventromedial nuclei in the hypothalamus as positive reinforcing, making the condition calm and causing a positive emotional response and coping to be effective or positive coping mechanisms (Sukarni et al., 2014). A calm state with positive emotions from relaxation through a holistic program, will be responded by neurosecretory in the hypothalamus which causes CRF secretion to decrease. A decrease in CRF levels will trigger a decrease in ACTH secretion by the pituitary gland, and eventually make cortisol secretion by the adrenal glands decrease (Pahlevi et al., 2017).

A holistic program can be used as a therapy to manage stress and increase immunity to stressors by strengthening the noble soul. This conclusion is also supported by some literature and previous study, that relaxation technique has been widely used as a method to reduce stress, blood sugar, body fat, hypertension, and anxiety (Raja et al., 2015).

Mind therapy on holistic programs includes remembrance therapy and yoga 
relaxation. Recitation is part of transcenddental meditation which involves a belief factor. Relaxation responses that involve adopted beliefs will accelerate the relaxed state or in other words, a combination of relaxation responses involving confidence will multiply the benefits derived from the relaxation response (Gratitude, 2012). The stronger a person's convictions combine with the relaxation response, the greater the effect they get. With the method of dhikr, all worldly problems are based on Allah (Kholiq, 2016).

Yoga decreases cortisol levels in the body, yoga can increase parasympathetic activity which can cause a decrease in the shooting of the paragigantocellular nucleus from the medulla to the locus ceruleus. Decreased locus ceruleus stimulation can reduce norepinephrine production, which results in relaxation, calmness and reduced respiratory and heart levels. A decrease in norepinephrine production for the paraventricular nucleus of the hypothalamus causes a decrease in corticotropin-releasing hormone and the hormone cortisol. Increased parasympathetic activity and the resultant decrease in blood pressure can make the autoreceptor relax, and cause a decrease in in $\gamma$-aminobutyric acid-ergic, which can cause inhibition of Supraoptic. Nucleus hypothalamus, which in turn can cause the release of arginine vasopressin (AVP). AVP is known to cause a positive impact. Finally, yoga can cause activation of the prefrontal cortex and increase glutamate transmission in the medial hypothalamic arcuate nucleus which results in the release of betaendorphin. Yoga has an influence on the response of the hormone cortisol and acts as an antidepressant (Nidhi et al., 2012).

It can be concluded that mind and soul therapy in holistic programs for patients with polycystic ovary syndrome can have an effect on reducing stress levels, it can occur because yoga and dhikr are part of relaxation techniques that can increase parasympathetic activity to remove neurotransmitters such as endorphin hormones and produce frequency alpha waves in the brain that can cause feelings of happiness, pleasure, joy, and confidence so that it can suppress the release of the hormone cortisol. Cortisol reduction will affect the decrease in insulin resistance levels, increase the motivation of PCOS treatment and strengthen confidence and efforts selfhealing in people with PCOS that can be carried out regularly and continuously in line with the cheap standard treatment therapy and proven effective in improving symptoms in PCOS.

\section{AUTHOR CONTRIBUTIONS}

Erna Yovi Kurniawati selected the study subjects, collected the data, provided holistic program, measured the cortisol serum level, and wrote the manuscript. Suharyo Hadisaputro and Agus Suwandono did the data analysis and interpreted the results of data analysis.

\section{CONFLICT OF INTEREST}

We declare that we do not have any conflict of interest.

\section{FUNDING AND SPONSORSHIP}

There was no external funding.

\section{ACKNOWLEDGEMENT}

We would like to thank to the Integrated Research and Testing Laboratory, Universitas Gadjah Mada, Yogyakarta for giving permission to do this study.

\section{REFERENCE}

Adisty NI, Hutomo M, Indramaya DM (2017). Salivary cortisol levels of representing serum cortisol levels in 
atopic dermatitis patients. Periodic Journal of Skin and Sex Health Sciences. 27(3): 170-5.

Amini L, Tehranian N, Movahedin M, Tehrani FR, Ziaee S (2015). Antioxidants and management of polycystic ovary syndrome in Iran: A systematic review of clinical trials. The Iranian Journal of reproductive medicine. 13(1): 1-8. https://www.ncbi.nlm.nih.gov/pmc/a rticles/PMC4306978/pdf/ijrm-13-001.pdf.

Bazarganipour F, Ziaei S, Montazeri A, Foroozanfard F, Kazemnejad A, Faghihzadeh S (2013). Psychological investigation in patients with polycystic ovary syndrome. Int $J$ of Health and quality of life outcomes. 11(1): 141. https://doi.org/10.1186/1477-7525-11-141.

Costello MF, Misso ML, Wong J, Hart R, Rombauts L, Melder A, et al. (2012) The treatment of infertility in polycystic ovary syndrome: a brief update. Australian and New Zealand Journal of Obstetrics and Gynecology. 52(4): 400-3. https://doi.org/10.1111/j.1479828X.2012.01448.x.

Helpman L, Penso J, Zagoory-Sharon O, Feldman R, Gilboa-Schechtman E (2017). Endocrine and emotional response to exclusion among women and men; cortisol, salivary alpha-amylase, and mood. Anxiety, Stress, \& Coping Int Journal. 30(3): 253-63. https://doi.org/10.1080/10615806.2016.1269 323.

Kholiq M (2016). Effect of dhikr on decreasing blood sugar levels in type II diabetes mellitus patients at Kendal I Sukodono Kendal Health Center Semarang, Indonesia: UIN Walisongo.

Marsh K (2009). Dietary Management of PCOS. In: Farid N.R., DiamantiKandarakis E. (eds) Diagnosis and Management of Polycystic Ovary Syn- drome. Springer, Boston, MA. https://doi.org/10.1007/978-0-387-097183_16.

Nidhi R, Padmalatha V, Nagarathna R, Amritanshu R (2012). Effect of the holistic yoga program on adolescent girls on anxiety symptoms in polycystic ovarian syndrome: A randomized control trial. International journal of yoga. 5(2): 112. https://www.ncbi.nlm.nih.gov/pmc/articles/PMC34101 $89 /$.

Pahlevi R, Putra ST, Sriyono S (2017). Psychoneuroimmunology approach to improve recovery motivation, decrease cortisol and blood glucose of DM type 2 patients with dhikr therapy. Ners Journal. 12(1): 6o-5. https://media.neliti.com/media/publicatio ns/119265-EN-psychoneuroimmunology-approach-to-improv.pdf.

Raja-Khan N, Agito K, Shah J, Stetter CM, Gustafson TS, Socolow H, et al. (2015). Mindfulness-based stress reduction for overweight / obese women with and without polycystic ovary syndrome: Design and methods of a pilot randomized controlled trial. Contemporary clinical trials. 41: 287-97. https://doi.org/10.1016/j.cct.2015.01. 021.

Rooney S, Pendry B (2014). Phytotherapy for polycystic ovarian syndrome: a review of the literature and evaluation of practitioners' experiences. Journal of Herbal Medicine. 4(3): 159-71. https://doi.org/10.1016/j.hermed.201 4.05.001.

Santoso B (2014). Polycystic ovary syndrome: Reproductive problems and challenges related to the indonesian women's lifestyle. East Java (Indonesia): Airlangga.

Saftarina F, Putri INW (2016). Effect of ovarian polycystic syndrome on in- 
creased risk factors for infertility. Journal of Majority. 5(2): 43-8. http://juke.kedobatan.unila.ac.id/index.p hp/majority/article/view/1076/916.

Shama M (2017). A review towards PCOS in ayurveda. World Journal of Pharmaceutical and Medical Research. 8(3): 372-4. http://www.wjpmr.com/.

Sirmans SM, Pate KA (2014). Epidemiology, diagnosis, and management of polycystic ovary syndrome. Clinical epidemiology. 6: 1-13. https://doi.org/10.2147/CLEP.S37559.

Stener-Victorin E, Holm G, Janson PO, Gustafson D, Waern M (2013). Acupuncture and affective symptoms and health-related quality of life in poly- cystic ovary syndrome: secondary analysis from a randomized controlled trial. Int J BMC complementary and alternative medicine. 13:131. doi: 10.1186/1472-6882-13-131.

Sukarni S, Mardiyono M, MDW Parvate (2014). 4T Zikr in Anxiety Reduction in Acute Coronary Syndrome Patients. Journal of Health Research. 3(2): 567-75. http://ejournal.poltekkes-smg.ac.id/ojs/index.php/jrk/article/view $/ 225$.

Syukur MA (2012). Sufi healing: therapy in Sufism literature. Journal of Social Religion Research. 20(2): 391-412. Available from: http://dx.doi.org/10.21580/ws.20.2.205. 